\title{
Labour Market, Wages and Their Policies in the EU Area
}

\author{
Dalina ANDREI, \\ Economic Forecasting Institute of the Romanian Academy,Bucharest \\ dalinaandrei@yahoo.com \\ Liviu C. ANDREI,
}

National University of Political Studies and Public Administration, Bucharest liviucandrei@yahoo.com

\begin{abstract}
Interesting and challenging is not exactly that economic thinking is divided between those who admit that labour would be a good negotiated on its specific market segment and those who don't, but other two-three aspects. The one is that those who do admit it are classic, neoclassic and (interestingly!) Marxian schools. The last thinkers certainly see it as pejorative. Interesting is equally that those who 'reject labour market concept' work around the Keynesian thinking school. The author of 'General Theory...' rejected the idea that employer and employee could ever be economically equal to each other and that labour could keep any real market supply specific behaviour. Thirdly, Keynes was the first one who pointed to unemployment as a real modern problem, but also interestingly his view on the same unemployment wasn't satisfactory for our present.

At present, unemployment is a problem and even an unsolved one for the European economy and for the EU Organization. The EU documents might indicate it as a problem (and not only economic) and a policy priority, together with the wages issue, but basically employment and wages cannot make any policy priority against economic targets like productivity, cost reduction and industrial efficiency.
\end{abstract}

Keywords: EU, labor market, wage, industrial efficiency.

JEL Classification: F15, J08.

\section{Introduction}

Council of Amsterdam (1997) $)^{1}$ emphasized the social partners' responsibility for ensuring correlation between high wages and a

\footnotetext{
${ }^{1}$ Treaty of Amsterdam, adopted by heads of EU member States and Governments on 16-17 July and finally signed on 2 October 1997 was intended to amend some provisions of the previous Maastricht Treaty (1992) on issues like: democratization, employment, freedom, security and justice, EU foreign policy, security and external links and institutional reforms.
} 
correspondingly high employment and for an institutional framework of wage perspective shaping. On this issue's background social dialogue here plays its traditional role and the first dialogue partners are of course governments. Public sector stays itself obviously significant in European countries and correspondingly governments still make the law in social dialogue even in such an advanced integration stage (Andrei 2011).

\section{Wages and payroll policy coordinates}

The wages pay belongs to social national, regional and sectional partners' responsibility in a decentralization philosophy. The general guidelines of economic policy in the EU issue some specific wage criteria as follows:

(i) nominal wage rising on the prices stability background,

(ii) real wage rising basing on the same for productivity, investment return and the wage's own purchasing power and

(iii) collective agreements reflect better and more pragmatically the productivity-labour skill scales within regions and sectors, i.e. on the whole EU region.

In the EU's view a moderate wage growth could follow the European Central Bank (ECB)'s price stabilizing target - i.e. all irresponsible wage growth would skip such endorsement. They wouldn't even be able to provoke inflation, as usually elsewhere, but competitiveness losses instead so clearing the way for intra-region import surpluses and then to unemployment here and there vis-à-vis a specific overall EU's elastic supply of goods and services.

For the other static view intra-Union wage differentials persist whereas actually needed to be included in a mechanism of competitiveness and profitability equalizing, of which rather general and healthy wage growth might be natural consequence. The Irish model of mid 80ies might be a good illustration for such a mechanism, i.e. wage moderation based future investments and productivity growth for new virtuous successive wage rises above the EU average and off any inflationary, competitiveness and unemployment inducing problems.

Back to social partners and to their up responsibility for wage policy, two more aspects to be emphasized. The one is made by the common currency bringing more transparency in about total costs and about their wage component in the EU member countries (i.e. no exchange rate fluctuation) with two more results within the region: labour mobility and high wages imported.

The other is that all wages rising over the productivity rising pace will condemn local and then region's competitiveness, investing profitability, so its attractiveness. That will affect in chain exports and new investments with 
unemployment consequences. However, even so it will be on longer terms that labour reducing and capital-labour substitution are able to remake wageproductivity correlation, be it on the harmful rising unemployment background. To be though noticed that such a scenario deducts a current need for keeping wage differentiation and fights the imaginable 'wage imitation' (Buch \& Piazolo 2001).

\section{Unemployment, its specific 'defy' and possible fighting}

See first the above transfer of monetary and other disturbances adjusting competences within the EU area for the following developments on unemployment. Since the mid 70ies employment was low pace rising so that the opposite unemployment rate did it five times higher -- i.e. employment rate was lowering from 67\% in 1961 about 7.0 percentage points in Europe, while in US and Japan the same rate was getting to $74 \%$. Plus, in Europe a double diminution is found, i.e. active (age) population lowering and the same for the one actively searching for work, here see 'discouraged workers' phenomenon.

As the result, in the pre-Euro period the EU labour market did face rather modest growth rates, as compared to both the other developed regions' and its own previous 60ies' cases (Gil-Robles 1998). And this while Europe also faced negative growths on all according to statistics: employed people, active (age) people and individuals looking for work. This was called the 'employment defy' and explicitly consists in concomitant labour policy perspectives of first remaking the 60ies picture, then rising employment through at least females employment stabilizing, an impact foreseen for achieving $70 \%$ employment level. When $67-$ $72 \%$ employment would be done in the European countries, unemployment in France and Germany could be eradicated (ibidem).

Seen from another standpoint the $60 \%$ employment rate level equals the $55 \%$ 'full time', meaning a partial unemployment in a limited free option environment. Moreover, unemployment here has high costs concomitantly with still founding an economic growth reserve for perspective, the same for perspective relaxing finances and social security when current unemployment would be expected to extinct. Just this aspect is that US and Japan are missing. Here, in Europe this might become a strategic reserve, a perspective investment resource to all long term resources as such that have already be mentioned by the Commission in November 1997 in its communication regarding environment and labour issues illustrated with sustainable consumption and production models (NewsHour 1999). 
Another issue is cyclical unemployment that was about $2 \%$ of active population in the eve of euro currency birth, in 1998. Actually this is half of the half of the opposite non-cyclical part of the same unemployment; or this is population constantly employed during the labour market cycling, equally this is currently ready to at least limited reconversion. In other words, of $10.7 \%$ total unemployment rate only $6.0 \%$ could apparently be ready for pretty fast absorption by labour market, i.e. at the primary job offer. Vis-à-vis the labour market, currently available skills do not yet seem obsolete, so market bottlenecks fighting might limit to just jobs creation.

The European Commission was going on encouraging member States to proceed to jobs creating and competitiveness promoting through investments, training and innovation, to develop industrial cooperation, to ensure market competition and finally to strengthen the State's public authorities' role in such a concern. The Essen EU Summit in December 1994 had here identified key areas for corresponding policies against unemployment, policies associated with those of wage cost reduction and of helping disadvantaged groups, e.g. young people. Despite these the EU member countries' average unemployment stayed about $11 \%$ of the active population. Then, the recession year 1996, here associated with State budget restrictions all over imposed by the earlier Union Treaty (1992) for the sake of new forthcoming convergence criteria, saw serious difficulties for jobs creation (Eurostat 2007).

Enough for identifying labour employment as the most harmful defy ever faced by the EU Organization. Nevertheless, responsibility firstly belongs to member States' authorities. Then, the EU Council meeting of Dublin in December 1996, when the Irish presidency was ending, reasserted the Union's commitment for labour employment strategies support; then at Essen again the Summit was coming to detail on these.

And besides the above issues and events coming in short run, in the long run unemployment might be expected to about 5\% resorption by structural policies applied.

\section{Improving payroll and labour market policies}

The old Treaty of Rome (1957) contains the primary EU's legal provisions related to labour's movement within the Community region(EUR lex Europa EU). The 1945-1970 year interval might be the one called ,gold era' of continuous labour demand, i.e. number of employees could at that time be integrated into the same Community's labour market, here included youth, women and foreigners. Then European Social Fund (ESF) was founded, but the labour market trend was coming to reverse during the next following years. So, unemployment 
came and then labour market policies needed for which the member States' role was correspondingly strengthening.

Later on, in 1986 the Single European Act (SEA) was recognizing and convincing the Unique Community Market; labour market was part of and its specific policy includes workplace healthcare measures. Gordian node of labour market policy was its basic definition as policy of employment, plus its correlation with other policies, e.g. of development, of competition, of price stability, of social protection.

Then, Treaty of Amsterdam (1997) has got some provisions on employment and social protection policies. EU member States were here called to cooperate for designing a common strategy on employment and that as a component of the enlarged objectives area of what was going to be called sustained development, i.e. together with competitiveness, but also competition, technic and technological levels, life quality, social and economic cohesion, equal chances and naturally high employment rates besides(Colloque Von Wogau 1998).

The EU member States moved the same year (1997) for a new meeting in Luxembourg and this was then able to reach the European Strategy for Employment, the same with ,Luxembourg process' all facing the labour market specific picture in Europe. This Luxembourg EU meeting equally initiated further reunions on the same issues, i.e. Cardiff (1998) - i.e. ,Cardiff process' also called ,economic reform and domestic market'--, then Köln (1999), Lisboa (2000), Stockholm (2000), Barcelona (2002).

Of which Lisboa (2000) gets particulaly significant event by its next following decade strategy towards EU becoming, the most dynamic and economically competitive region world-wide'. Or this was including that the limit year 2010 was expected for a total employment rate of $70 \%$ and a women corresponding one of $60 \%$ given a concomitant creation of about 5 million jobs. Concomitantly again, European Social Fund (ESF) would be strengthening its role for the employment policy on its financing side and for its components like unemployment fighting, equal chances, labour resources integration on market and human resource development.

In March 2005, a half decade time from the above ,Lisboa Strategy' adopted, strategic objectives were strengthened already, as the European Council's (heads of member States and Governments) meeting found also in Lisboa, i.e. the ,new Lisboa strategy' (EC 2005). This last was reiterating objectives of economic growth, employment rise both these basing on the innovation ,axis' and on the ones of knowledge, investments attracting and social cohesion. 


\section{Policy directions}

Council of Amsterdam (1997), again, adopted Employment and Labour Market Guidelines on its resolution chapter related to employment. These Guidelines were carefully defined as correlated and coordinated with general economic policy orientations, then transmitted to national action areas, i.e. also see Council of Cardiff reunion next year (June 1998). Strategic directions were here revealed as follows:

(1) Adjustments made on general lines with specific factors. These are policy measures for labour market tensions preventing, e.g. human capital formation and improvement, active supporting measures for young unemployed and long term unemployed people, especially when economic growth due to employment bases.

(2) Promoting entrepreneurship, here apparently indirectly involved issue, would be related to the reform of goods' and services' markets and directly regard the main blockade of today's labour market, i.e. too low job creation pace.

(3) Promoting adaptability of businesses and employees moves focus to microeconomic bases of sustained development and employment rising. It is enterprizes to be encouraged for productivity and competitiveness raised and besides Government and social partners might help for modernizing work organising.

(4) Equal chances promoting, equally for employment rise and here regarding sex, labour-familly reconciliation and disabled persons.

(5) The new mixed concept of ,flexi-curity' - actually a mix between labour market flexibility, on the one hand, and jobs security on the social ground on the other. Or, labour market needs flexibility in order to facilitate other policies' exercizing. In concrete terms, flexicurity means combined policy measures for the two different objectives, e.g. a presumable measure to relieve redundancies on the labour market to be taken along with others to either increase unemployment benefits, or to create opportunities for professional reconversion ${ }^{2}$.

2 Documents here see how such practice was successful in a country like Denmark, i.e. unemployment dropped below $4 \%$ concomitantly with unemployment benefits keping high. Despite this, some other ambiguities and empty spaces remain on ,Lisboa agenda' implementing. Policies regarding labour market address to a European (EU) specific space with specific rigidities, especially on labour supply side, and with a strong national (mamber States') brand. So that the primary judgment result consists in the need of EU policies here involving national and domestic actors' contribution, as mandatory. Shortly, the Danish example is one of keeping high wages during implementing labour market policies impopular by definition, but finally proven 
Also recall from above the ,Lisboa process'. On 2 February 2000, the Commission presented to the Council of Lisboa a , Revitalization Agenda' that was containing both a 3\% a year average economic growth and an about 6 million jobs creation up to 2010, in association with new directions of: the region turning into an attractive one for both investment and potential employees, into the one of knowledge and innovation and finally jobs creation, once more(EC 2004).

\section{Braking capital-labour substitution}

Such a delicate issue technically needs somewhat apart treatment since the structural reforms might here engender what was already called 'apparent productivity growth' or even 'apparent productivity'(Commité des Régions 2001). This last is exactly what might be able to seriously erode the real productivity, on its side. In other words, apparent productivity devolves from both braking capital-labour substitution and perfidious working time reduction ${ }^{3}$. The idea is that productivity gains related to capital-labour substitution not to affect real wage level, i.e. that wages do remain on their previously given scale. And so the microeconomic effect is done, i.e. unitary labour cost goes down in favour of rather short term and significant profitability gains for enterprises.

And then the macroeconomic effect results from these gains and then properly clear the way for next future employment rising policies. Or these last might be even classic way, i.e. just investing in a higher pace than the one of resulted productivity growth and this at least on a given encouraging market demand background. Do not equally omit the other two premises of jobs creation: that sectional reform (changing) would be accepted while human resource formation and labour mobility and that economic growth rate would be as high as supporting unemployment diminution, i.e. difference between jobs creation and destruction as presumably positive number.

Another approach in context -- i.e. of enlarging employment by jobs creation and of capital-labour substitution, here including the apparent productivity issue -- regards other activities (jobs) (re)absorbed, be they higher costs as related to their corresponding productivity. Two types of measures might be here considered as follows:

successful. On the other hand, Denmark is a small country that belongs to Northern Model inside the EU area, a fact asking the question whether the same policies could really be able to generalize within the Community-Union region, together with the same specific Danish experience of employers-employees dialogues.

${ }^{3}$ And this recalls some unwished phenomena of 1982-1989 and 1992-1996 year intervals. 
(1) Widening the wage scale towards its bottom, that implies a 20-30\% wage costs for less skilled jobs - that was in the US in 70ies and 80ies. It is indirectly that here, in Europe, such a measure would suppose unemployment allowances and social works correspondingly reduced in order to avoid the so called poverty trap. It is concomitantly true that such a method would collaterally enlarge the income gaps in Europe, plus it would make the poor employees issue, i.e. those missing decent incomes, and in chain this would make social exclusion, contrary to the aimed cohesion, this time inside the employees category despite here recalling rather the unemployment vicinity. And it is also concomitantly true that social benefits reduced this above way might get balanced by new forms of social transfers, a fact that would remake the previous budgetary pressure. In a word, the US concept of 'earned income tax' would meet a quite different environment in Europe, e.g. for income compensation of long term unemployed people.

(2) Reducing non-wage costs. In most EU member countries the share of labour taxation equalizes the amount of social security contributions. The last are likely complex structure and priory affect low wages either.

Recall also that these social security contributions had been once founded as expressing solidarity in a period when contributions were higher amounts whereas low unemployment, balanced budgets and so solidarity degree was obviously higher than today situation. Today, the former social generosity faces increasing difficulties of survival if not a real vicious circle is here to talk about: social contributions and increasingly important tax repercussions point to lower-priced assets in relation to potential beneficiaries ${ }^{4}$. The effect of this labour taxation increase will be the same increase of both overall labour costs on the new production unit and labour contributions on GDP, which is actually the same issue and they have got as high as 4.6 percentage points during the 1970-1981 decade time. Between 1981 and 1997, wage rigour in the region has successfully compensated for this growth. And meanwhile wages on GDP lowered by 6.0 percentage points that made unit labour costs relatively lower than the ones of early 70ies. Enough to find that actually such taxation harms wage incomes only. Plus, this

\footnotetext{
${ }^{4}$ Gil-Robles (1998) here has the direct example for social security contributions in GDP in EU member countries average that increase from $10.5 \%$ in 1970 to $16 \%$ in late 90 ies - just mentioning that these contributions are just one of the whole tax burden on labour.
} 
trend is expected to prolong in the next timeframe, in which context at least profitability, on the contrary, might be favoured.

Such description is though the one in which, vis-à-vis lowering costs tax burden stays on individuals, especially on those with low incomes, i.e. at the base of the wage scale. Or, this is the fact that pushes jobs of low pay and skill off the labour market, here including towards the black market always ready to absorb them.

It is concomitantly obvious that the same high tax burden lowers the labour costs in the employers' advantage. But this is just primary effect - in reality generalizing such a phenomenon for wage moderation could then brake the same labour cost reduction onwards. In such new circumstances the option between giving up some social advantages for individuals and a new budgetary effort for supporting them would feel forced on the employment stabilizing bases.

Then, a presumable opposite labour tax reduction would be supposed to search for alternative compensation sources, e.g. environment or other taxes, when non-inflationary and/or no other harmful consequences. Basically, tax reduction, according to experience, proves more highly effective when exactly focused on (limited to) population groups, e.g. youth, unemployed of low skill and long duration. Besides, the same experience does indicate that taxation measures taken usually need complementary ones, this time for actively recovering labour resources, e.g. through education, apprenticeship, trainingretraining. For which, social transfers - e.g. unemployment benefits, publicprivate partnerships - could fund these as for limited budgetary effort. This might be the background of taxation effectiveness associated with social supportability, as correspondingly.

However, such a labour tax reduction is required in a systemic framework of social security and taxation areas, i.e. given a whole European picture including data of population aging, healthcare costs' implosion, poverty trap, the need of environment specific taxation.

Given all these above the classical wage-productivity correlation ensured is the one keeping long term chances for employment, here including for it having back jobs that yet belong to the underground economy. This complex of measures taken actually is about combining fiscal reforms with associations and collective negotiations. But facing given labour market developments, wage evolving might be seen as normal and considering existing return and perspective demand growth. A context in which technological improvements are expected to push all factors' productivity up and labour-capital substitution to go down(Gil-Robles 1998). 


\section{Working time}

Working time reduction was rightly seen as a progress achieved symptom in industrialized world during the whole $20^{\text {th }}$ century. The completion of this aspect was that regarding such progress made obvious when significant economic growth and high employment. The same last century experienced the so called 'work-free time arbitration', a phenomena conjunction of real wage growth with productivity redistribution among activities and of course with working time reduction. Or, this trend might be expected to come back and strengthen always on economic growth background as well as to be equally specific to work environment and life quality improving.

European Commission thinks in context that limiting the weakly working time to 48 hours and the daily one to 11 hours comes in the double favour of employees' health and jobs securing. The old European Commission's Directive 93/104/EC of 23 November $1993^{5}$, as amended by Directive 00/34/EC of 22 June 2000 (EUR lex Europa EU), continues to shape its outline by new adjustment proposals here coming on an upward legislative spiral ever-since. Otherwise, in Europe three cultural poles work in such a respect, i.e. the 'Anglo-Saxon' pole mainly pleading against short working time, namely against the 'Northern' pole, and the 'Latin' pole at 'the middle' of the previous two thinking options by advocating for medium-time work (Council of the European Union 1993).

Another option for reducing working time bases on such an experience coming out in recession and high unemployment circumstances, i.e. such reduction might be one of the fastest unemployment reduction policy measures appropriated to the short time. Supporters of such a thesis assume quality of labour as given (exogenous) and so fighting unemployment as such needs a generalized working time reducing for all individuals. But some problems for this reasoning are not missing.

\footnotetext{
${ }^{5}$ Subjects of this Conference: arrangement of working time, humanizations of work, occupational safety, organization of work, working time
} 
Figure 1 : Working time in EU member countries

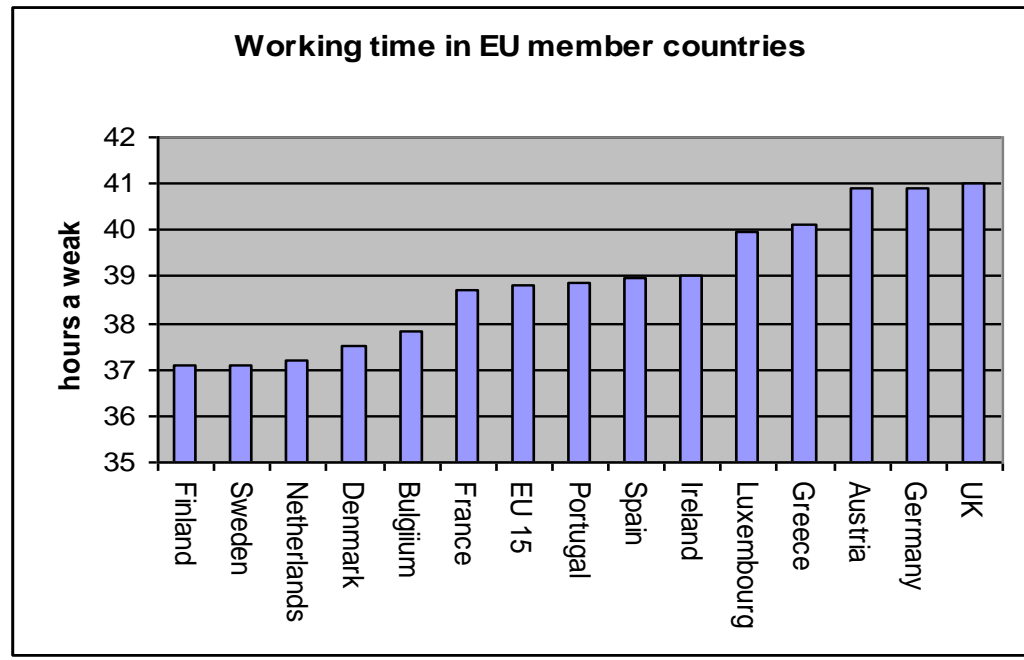

Data source : Eurostat:' EU Trends-Tendences', Brussels, 13 September 2007, page 69

- Some efects of law enforced working time reduction might be seriously unwished especially for enterprises with (previously) well determined capital and labour resources; which might even be the very challenge. These enterprises might face difficulties of keeping constant their total working time needed related to all aferreent employees, might see themselves forced to temporarily swich off some machine-tools in context, so production and/or productivity would see themselves affected. At the macro scale, these effects would turn to economic growth affected, even to production and welfare shortages that in turn would harm on employment in a quite vicious circle.

- Real wage rising rather needs decreasing pace from the very beginning and onwards to prevent all imginable labour cost inflating, profitability reduction causing downward effects on investment and on productive potential, as well as conflictual social impact on the background of welfare distribution.

Last, but not least any specific measure favouring working time reduction at the enterprise micro scale always needs to consider a long list of factors: from local conditions and those negociated with social partners to admitting this reduction as reversible in principle and ever considering working time reduction 
in a secular trend and process context. Authors suggest measures of this kind taken together and correlated with others like fiscal advanteges created and, again, jobs creation.

Finally, except for its reducing, working time is also seen in its maximal use imperative context, of course here assuming both given employment and the one found in new part time or ,volunteer' forms. New law adapting will be here required, plus here considering sensible differences among EU member countries on this.

\section{Conclusions. The labour market's scenarios}

There is no any secret in that labour market stays controversial issue for analysts ${ }^{6}$, despite or together with its high interests here related not only economically, but also socially and politically (PBS online News Hour 1999). Let us first keep for this last paper chapter the two alternatives and opposite scenarios. The optimistic scenario is the one in which this market segment drops its previous overregulation. Employers will apply their own wage and employment levels as variable, i.e. adjustable according to macro business cycle. Employees, in exchange, will feel free to move both within the region and towards industries in need of labour.

In its opposite pessimistic scenario, labour market will jeopardize the unique common European currency's survival. Political interest will be dominant on the economic one, trade unions strengthen for political decision making and during down business cycle intervals member States will see themselves missing political tools to counteract and repair bad effects. The bad labour market scenario could easy turn into the catastrophic one.

Then, let us have the immediate reality, the one 'between the opposite scenarios' and in the short run. Or, what we have here is really contradictory. On the one hand, strong trade unions in Europe prove able to break reforms that are opposite to their power; on the other the just existing and working unique common currency certainly is a European construction of a larger forces' compromise done. Recall the above positive scenario, in which labour market forces would predominate and make it against trade unions and overregulation just to emphasize that such an alternative would also make the European specific picture similar to the American one. However, the basic equation of such a scenario will ever be stability and growth achieved as according to the old Pact"s

\footnotetext{
${ }^{6}$ Recall the above paper abstract as well.

7 i.e. Pact of Stability and Growth, completing the previous Euro currency's Convergence Criteria, in the Annex of the 'Treaty of Union' (Maastricht, 1992).
} 
provisions that have already faced important difficulties during the 2008 Lehman international crisis and some scholars already see it partly obsolete.

Just here adding what the Euro currency and advanced integration (Andrei 2011) here brought in together with this new century, namely, besides radical economic terms, something changing the old liberal society into a new contractual one, in which, besides or even instead of winners versus losers of the old society (e.g. labour market flexibility, versus trade unions and overregulation), there might be possible a unique winner that certainly will be Europe.

\section{References}

[1] Andrei, Liviu C (2011): Economie Europeana.. Bucharest : Editura Economica Second Edition

[2] Barber, Tony (2001)-- The Governing Council's balancing act. August 82001 14:11GMT | Last Updated: February 82002 11:44GMT (2001)

[3] Buch,C \& Piazolo,D (2001): Capital and Trade Flows in Europe and the Impact of Enlargement. Kiel Working Paper No 1001

[4] Colloque Von Wogau (1998) : « Discours de clôture »- Bruxelles - Wednsday, 23 September, 1998

[5] Commission Européene (Commité des Régions/2001): Économie de la zone euro et de I'Union. N CdR 1060/2001. Brussells, 17 September 2001

[6] Council of the European Union (1993): Council Directive 93/104/EC of 23 November 1993 concerning certain aspects of the organization of working time

[7] European Commission (EC 2005): The Cechini Report 2005

[8] European Commission (EC 2004) /Directorate General of Economic and Financial Affairs (2004): EMU after Five Years, 15 June 2004

[9] Eurostat (2007) : EU Trends-Tendences, Brussels, 13 September 2007, page 69

[10] EUR lex Europa EU , Web page. Retrieved from : / http://eur-lex.europa.eu/legalcontent/EN/TXT/?uri=CELEX\%3A31998L0070

[11] Gil-Robles, José Maria (1998) - L'euro sera une des monnaies les plus stables du monde /Croissance et emploi dans le cadre de stabilité de I'UEM. Some reflections on economic policy orientations of 1998 (view point of the president of the European Parliament)

[12] Ignat, Ion (2002): Uniunea Europeană. De la Piaţa Comună la Moneda Unică. Editura Economică. 2002

[13] Jinga, Ioan (2000): Uniunea Europeană. Realităţi şi Perspective. "Lumina Lex". Bucharest. 2000

[14] PBS online NewsHour (1999) -- Banking The Euro. The Euro unveiled. January 1, 1999. On line: http://www.pbs.org/newshour/bb/europe/jan-june99/euro_1-1.html

[15] Marin, D, Socol, C, Marinaş M (2004) : Economie Europeană. O Prezentare Sinoptică. Editura Economică. Bucharest

[16] OECD(1999): EMU: Facts, challenges and policies. On line: http://www.oecd.org/news_and_events/publish/pb99-06a.htm 
[17] Pelkmans, Jaques (2003): Integrarea Europeană. Metode şi Analiză Economică, IER translation into Romanian. Bucharest 2003

[18] Profiroiu, Marius \& Elena Popescu (2004): Politici Europene. Editura Economica. Bucharest

[19] Tsoukalis, Loukas (2000) -- Noua economie europeană. ABC Publisher. 2000. Translation into Romanian by Irina Dogaru \& Nicolae Negru 